\title{
Muséologies
}

Les cahiers d'études supérieures

\section{Scene: Mare Street. Hackney. Late afternoon, early fall. Not long before the Frieze Art Fair}

\section{Knowles Eddy Knowles (Robert Knowles, Michael Eddy, Jon Knowles)}

Volume 7, numéro 1, 2014

Le dialogue dans les musées d’art contemporain

URI : https://id.erudit.org/iderudit/1026657ar

DOI : https://doi.org/10.7202/1026657ar

Aller au sommaire du numéro

Éditeur(s)

Association Québécoise de Promotion des Recherches Étudiantes en

Muséologie (AQPREM)

ISSN

1718-5181 (imprimé)

1929-7815 (numérique)

Découvrir la revue

Citer ce compte rendu

Knowles Eddy Knowles (2014). Compte rendu de [Scene: Mare Street. Hackney. Late afternoon, early fall. Not long before the Frieze Art Fair]. Muséologies,

7(1), 239-246. https://doi.org/10.7202/1026657ar

Tous droits réservés (C) Association Québécoise de Promotion des Recherches Étudiantes en Muséologie (AQPREM), 2014
Ce document est protégé par la loi sur le droit d'auteur. L'utilisation des services d’Érudit (y compris la reproduction) est assujettie à sa politique d'utilisation que vous pouvez consulter en ligne.

https://apropos.erudit.org/fr/usagers/politique-dutilisation/ 
Carnet un

Scene: Mare Street. Hackney.

Late afternoon, early fall. Not long before the Frieze Art Fair.

Knowles Eddy Knowles 


\section{Knowles Eddy Knowles formed in Halifax, Nova Scotia, during the winter of 2004, and have continually inves- tigated the rudiments of collaboration with an attentive- ness towards the dynamic forces of space, context, the serendipity of chance circumstance, and unforeseen contingencies. They make productive what most would deem a digression.}

In 2004, Robert Knowles (b. 1983, Manchester, UK), Michael Eddy (b. 1981, New York, NY), and Jon Knowles (b. 1980, Oshawa, ON) dispersed to various points on the globe, and are now currently based in London, Beijing, and Montreal.

As a collaborative group they work remotely from each of their own particular localities, and periodically come together to produce exhibitions, commissions, research projects, performances and other discursive situations in venues such as: Informal Architectures residency and publication (Banff Centre), TENT (Rotterdam), Portikus (Frankfurt), Apex Art (New York City), Presentation House Gallery (Vancouver), Form/Content (London, UK), Fabbrica del Vapore (Milano), Centre de Recherche urbaine Montréal (MTL), R O O M (London, UK), Museo Studio del Tessuto (Como), Vitamin Creative Space (Beijing), Next Wave Festival (Melbourne), Galérie Séquence (Chicoutimi), Leonard \& Bina Ellen Art Gallery (Montreal), and Plug In ICA (Winnipeg).

Knowles Eddy Knowles' piece stems from a project we have been working on for several years, and which has taken the form of an archive of art works and documents, a series of performances and sculptures, and a perpetually unrealized curatorial proposal. Plainly stated, it is about the culture of tobacco consumption. Meanwhile, it also folds in some of the specific and real anecdotal aspects we have experienced around these various iterations, which in turn can be observed as generic art world relations (artists, institutions, and their gatekeepers).

knowleseddyknowles@gmail.com 
Leaning against the brick archway, a light greeting followed literally by a lighter. The face emerging from its bow in the inaugural white paper smoke, which has such a neutral connotation (or maybe neutralizing, like burning records and documents), opens itself to the distraction of the road and its minutiae, heightened anodynely by the erotic tension of standing quietly next to someone else.

"What did you think of that?", a footstep on the broken ice, and parried back comes the mild wince and see-sawing hand of a figure prone to pleasantries in gesticulation. Legible, the real thing. He or she then draws a little closer. "Sucks to be stuck out here. I'll bet you remember the days of the communal pack, on the table, within arm's reach.

Actually, that's interesting, that word, pack..."

Another gently telling gesture. First smoke of the day? Needs massaging?

Why smoke electronic cigarettes? E-cigarette benefits

- Cost less than $1 \backslash 3$ the cost of regular cigarettes

- You can smoke in non-smoking places - Starbucks, casinos, bars, offices, planes, trains \& automobiles!!

- Electronic cigarettes (E-cigs) are a revolutionary new alternative to traditional cigarettes.

- E-cigs simulate the smoking of traditional cigarettes in every way. It looks, feels and tastes like a cigarette.

- E-cigarettes are not banned under any no-smoking laws of Canada

- Electronic cigarettes produce no second hand smoke

- No more smell of tobacco smoke in your clothes and hair with e-cigarettes

- Electronic cigarettes contain no tar, chemical additives or carcinogens seen in regular tobacco products

- No nicotine stained teeth and hands

- Forget about cigarette burns, lighters and dirty ashtrays

Are you tired of:

- Going outside every time you want to have a cigarette

- Getting the nasty looks and comments

- Your clothes always smelling of smoke

- People telling you to "just quit"

- Running to the corner store every time you run out

- Paying the ridiculous price of buying cigarettes

- Stains on your fingers and teeth 
"But actually, here we are outside, and then we may have never even met inside. Even though there are ways around that. Like how they do it in airports, right? Like little glass pavilions? I once saw one of those built for just one person. Brings to mind another case, during the last days of indoor smoking, where a coffee shop pioneered a large glass wall to enclose the smokers. Nevertheless bagels and donuts still tasted like musty tobacco. Come to think of it, I think it was an artist who thought that one up. And now, only a generation later, placed in the middle of a busy art fair, the smoking pavilion seems neutralized tenfold. Only an artist, right?"

Hardly a budge.

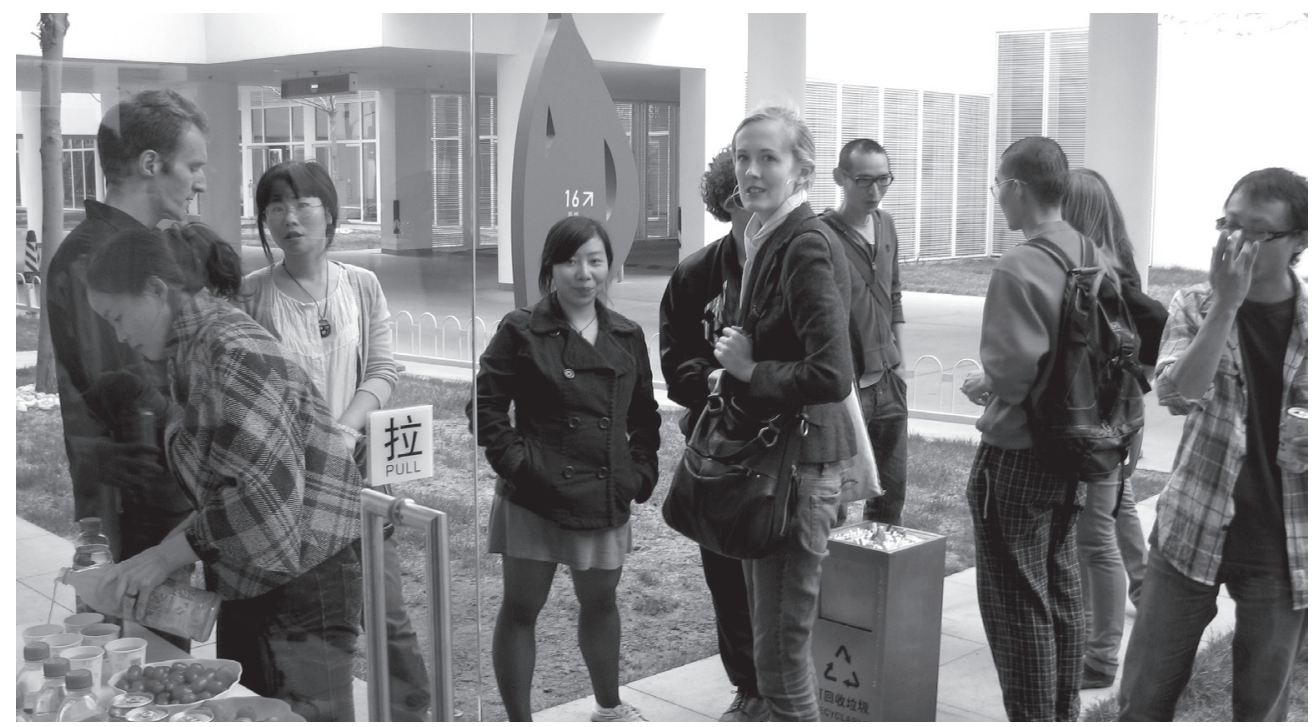

We heard an anecdote... (My other ashtray is a Donald $J u d d)$; sculpture and performance by Knowles Eddy Knowles for the exhibition"Portrait of Self-Exile" at Vitamin Creative Space's the shop, 2009.

(C) Knowles Eddy Knowles [Photographer: He Cong] 
"It's kind of funny..." partnered with a very natural pause, "I have a friend, an artist friend, who keeps pointing out all these art works that have cigarettes in them. She seems to be obsessed with it. Oh, listen to me, just blabbing away, and forgot to introduce myself. My name is Knowles Eddy Knowles. What do you do?"

With a surprising voice, a brassy hoarfrost soulful gong, "I am a curator." Finally, a foothold.

"Like an art curator? Ha, that's really something. Gee, my friend would be tickled pink if I told her I ran her idea by you. Would you mind?"

A look toward the door, and finding the route blocked by the interlocutor, fingers another cigarette. You have approximately five minutes.

"Well, if I remember correctly, her idea goes like this: The exhibition is organized around the shape of a body. We begin with the fingers. They reach out and touch the outside world, they point at you; they indicate you, but they themselves are marked-they aren't divine phalanges. Nevertheless you comply, and-like a secret handshake knotting with your feet-you walk into the exhibition under the tenting arch between index and middle fingers.

"After a solid left turn in the gallery, you transition to the hair and lips section. The arrangement in the gallery is modeled on dialoguing whispers, so as to resemble the chitchat between co-workers during a lunch break. This is where ideas are initiated, the impromptu brainstorm where they are smuggled into the intellect, wising you up through peer pressure.

"Proceeding these initiations are works themed on the mouth, tongue, and teeth-frontality, directness, rationality, articulateness, presentability, design and activist propaganda... do you read me?" Knowles Eddy Knowles draws closer, straining for saliva, abandoning hopes of fresh breath.

"Once you're getting really inside, that's when you actually meet the outside: the skin, this cover, this weathered thing, this dead crawling organ that is the source of most beauty but is really disgusting if you think about it. This part is like the mirror, where your self-image is melted in with the liquids of ideal perfection that you either alloy with or are rejected from. Adbusters, Richard Prince, Bernadette Corporation, 'Fresh Acconci' the art video. It's an exhilarating moment, and kind of goes against our expectations, doesn't it?" 


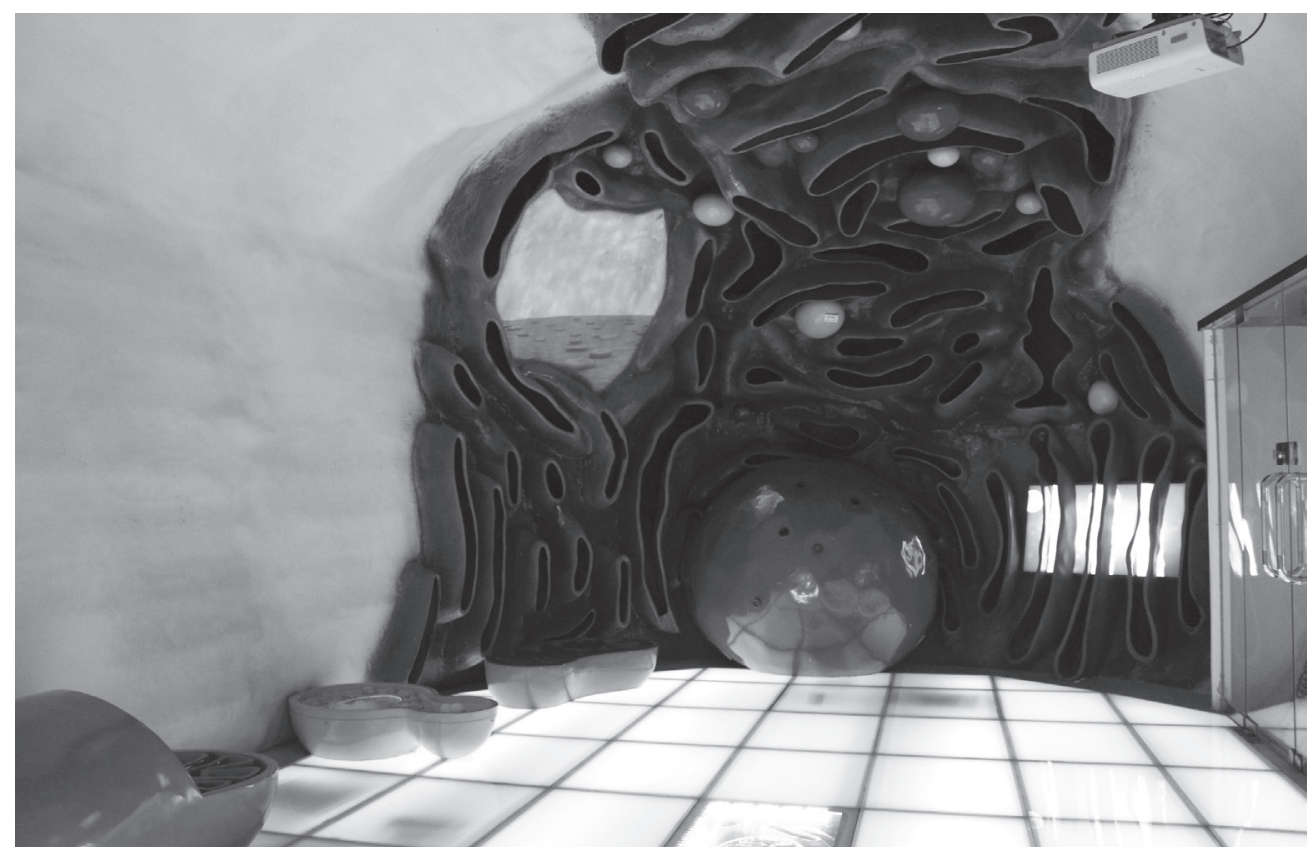

Interactive display at the China Science and Technology

Museum, 2012

(c) Knowles Eddy Knowles [Photographer: Michael Eddy]

"Then in the next section you arrive to a concentration akin to a node in the network of veins and blood circulation, and you notice aspects that have been with you the whole way, just undercover, gradually being manipulated through previous galleries; your blood pressure, pulse rate, and the temperature of your hands and feet will all return to normal by this point." Noticing some vague uneasiness in the curator, "figuratively speaking, of course.

"The lungs are really ground zero. Hung like a Parisian salon, the organizing principles are nonetheless openness, throbbingness, transformation. The breath is a grounding rhythm, it supplies to the other faculties their legitimacy, their functionality, but what it takes in is in fact quite ambiguous. Graphic representations; surrealism; automatic associations; where the dematerialized is re-materialized; this is actually the region of the lung.

"Some may attribute this to the brain, which is next door, but the brain is more honed to the perceptual triggers and intertwined psychological judgments, and it is of course much more about the potentiality inherent in the tension between doing and not doing. There you find reluctant painters, bathetic scheisse sculptures, and clever and sad 
things like that, alongside kind of non-things, strobe lights, tinsel, Gutai remakes, Fluxus games and stuff."

Unraveling or planning a trip? Be Seen! Go Green!

Going on a trip? Whether taking a train across Canada or flying to your favourite destination, you no longer have to worry about the long trips with patches or the white knuckling cold turkey approach.

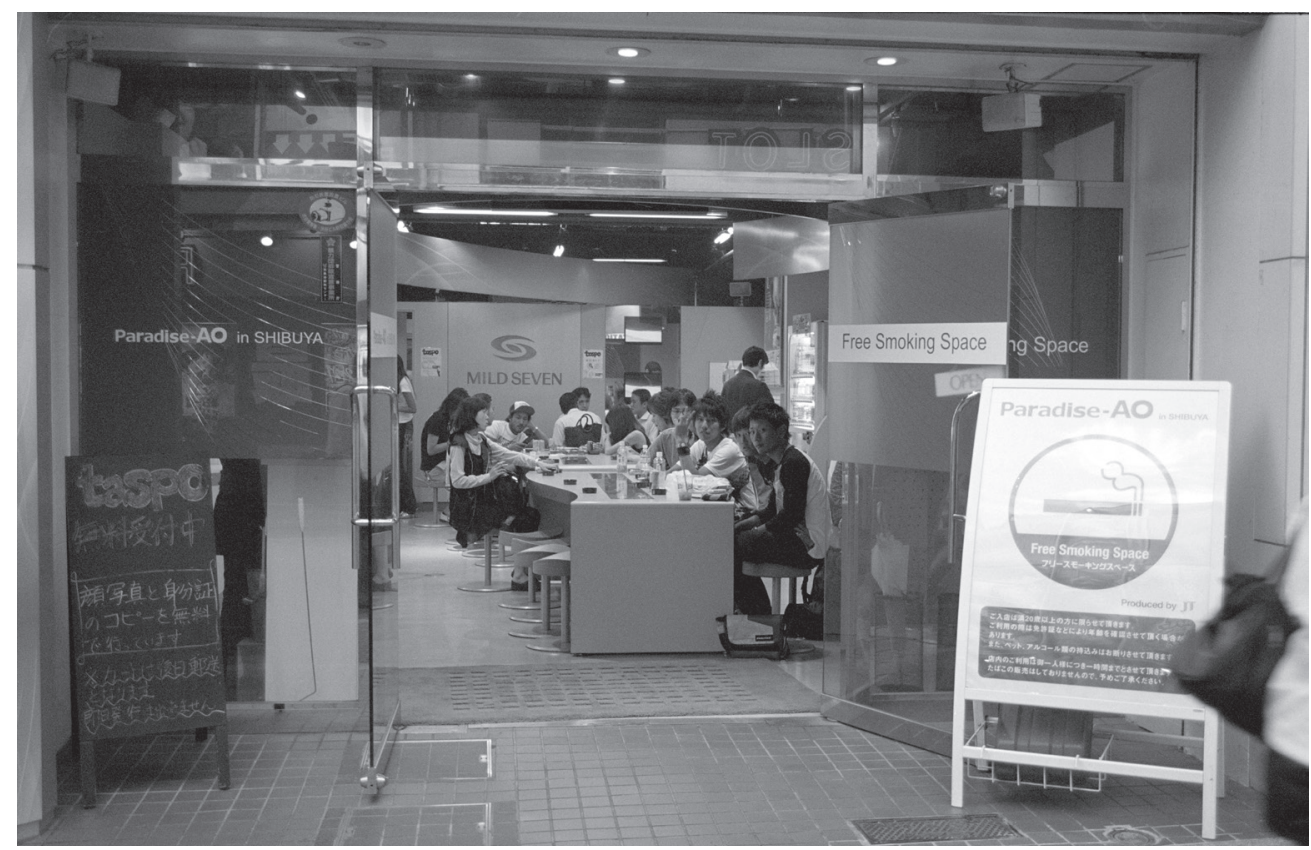

Paradise-AO in Shibuya, 2009

(C) Knowles Eddy Knowles [Photographer: Michael Eddy]

"Lastly, you come to the heart, which is by the exit; the heart, last thing to give up, is the space of sheer brute repetition, but also murmuring, jumping, surprises, and passions. Expressionism, structural films, and Op-art. There is also a door next to the exit that leads you back on an alternative route through the exhibition, like some kind of new lease on life.

"Now, I know this sounds, on the surface of it, kind of like the Museum of Modern Art, reconfigured. Not true. Keep in mind that every work in this project has some reference to tobacco in-"

A break in the curatorial membrane, shocking elation, and with effortless ease, Knowles Eddy Knowles' construction is bypassed for some shadow figure emerging from behind. With a "Hey Claus, how are you, 
nice to see you" coupled with one of those double-cheek kisses, the entrance has become the exit.

Knowles Eddy Knowles grabs the curator's elbow, says, "I hope you die of emphysema."

\section{THE END}

Alternate ending \#1

"What did you say?" Claus also pauses, his mandibles frozen, smooch-extended.

"I said, that sounds fascinating. Does your friend have a name?" "Yes, she does. Do you have a card I could give to her?"

The curator and Claus exchange wry glances, then a card is withdrawn from a pocketbook, and the gates of Eden stand ajar.

\section{Alternate ending \#2}

"You people make me sick. It's always the same cabalistic incest. But you know what I know? It's all done out of fear. Your little associations, your self-aggrandizing panel discussions and self-presentations: you feel they protect you from total oblivion. And so your delectation in compromise! The fact that you willingly consort with the enemy! How you won't take a stand unless to highlight yourself! Your vapid mantras to the lowest common denominator! And this conceals the reality that you're the most well-supported class, keeping your class interests A.K.A. your network sustained by a monopoly on speech and knowledge. You know, I used to feel sorry for you, how you're forced to play a character that you never really identify with, or only insofar as the will to power is written into this role. But you choose this! It's your own subjugation you're choosing! And in doing so, you force others into endless struggle. When will your generation face up to its crimes!"

Claus and the curator grab their mops and turn back into the space, coughing. 